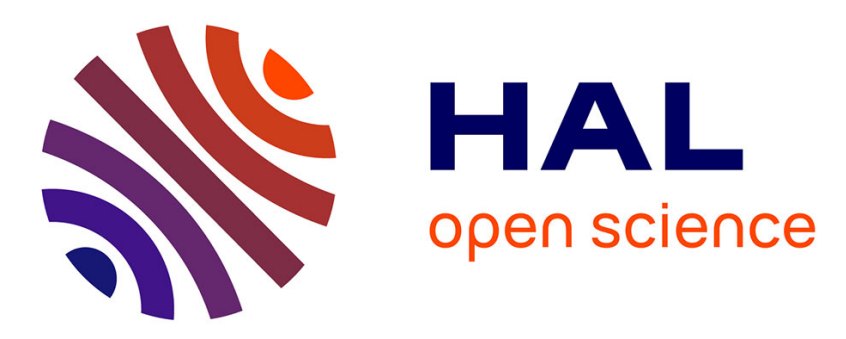

\title{
Microstructure Evolution in an Aluminum Cladded Sheet during Vacuum Brazing
}

Cécile Bernardi, Alain Hazotte, Nathalie Siredey-Schwaller, Thierry Mazet, Jacques Lacaze

\section{- To cite this version:}

Cécile Bernardi, Alain Hazotte, Nathalie Siredey-Schwaller, Thierry Mazet, Jacques Lacaze. Microstructure Evolution in an Aluminum Cladded Sheet during Vacuum Brazing. Materials Science Forum, 2014, 790-791, pp.355-360. 10.4028/www.scientific.net/MSF.790-791.355 . hal-01167219

\author{
HAL Id: hal-01167219 \\ https://hal.science/hal-01167219
}

Submitted on 24 Jun 2015

HAL is a multi-disciplinary open access archive for the deposit and dissemination of scientific research documents, whether they are published or not. The documents may come from teaching and research institutions in France or abroad, or from public or private research centers.
L'archive ouverte pluridisciplinaire HAL, est destinée au dépôt et à la diffusion de documents scientifiques de niveau recherche, publiés ou non, émanant des établissements d'enseignement et de recherche français ou étrangers, des laboratoires publics ou privés. 


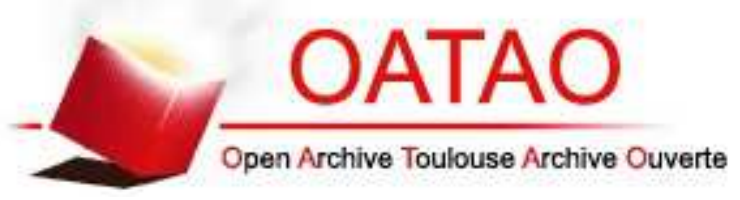

\section{Open Archive TOULOUSE Archive Ouverte (OATAO)}

OATAO is an open access repository that collects the work of Toulouse researchers and makes it freely available over the web where possible.

This is an author-deposited version published in : http://oatao.univ-toulouse.fr/ Eprints ID : 14014

To link to this article : doi: 10.4028/www.scientific.net/MSF.790-791.355 URL : http://dx.doi.org/10.4028/www.scientific.net/MSF.790-791.355

To cite this version : Bernardi, Cécile and Hazotte, Alain and SiredeySchwaller, Nathalie and Mazet, Thierry and Lacaze, Jacques Microstructure Evolution in an Aluminum Cladded Sheet during Vacuum Brazing. (2014) Materials Science Forum, 790-791. pp. 355360. ISSN 0255-5476

Any correspondance concerning this service should be sent to the repository administrator: staff-oatao@ listes-diff.inp-toulouse.fr 


\title{
Microstructure evolution in an aluminum cladded sheet during vacuum brazing
}

\author{
Cécile Bernardi ${ }^{1,2, a}$, Alain Hazotte ${ }^{2, b}$, Nathalie Siredey-Schwaller ${ }^{2, c}$, \\ Thierry Mazet ${ }^{1, d}$, Jacques Lacaze ${ }^{3, e}$ \\ ${ }^{1}$ Fives Cryo, 25 bis rue du Fort - B.P. 8788194 Golbey Cedex, France \\ ${ }^{2}$ Laboratoire LEM3, Saulcy, Ile du Saulcy F-57045 Metz - Cedex 01, France \\ ${ }^{3}$ CIRIMAT, ENSIACET 4, allée Emile Monso - CS 44362, 31030 Toulouse Cedex 4, France \\ a cecile.bernardi@fivesgroup.com, b alain.hazotte@univ-lorraine.fr, \\ ${ }^{c}$ nathalie.siredey@univ-lorraine.fr, ${ }^{d}$ thierry.mazet@fivesgroup.com, ${ }^{\mathrm{e}}$ jacques.lacaze@ensiacet.fr
}

Keywords : heat exchangers, brazing, aluminum alloys, microstructure

Abstract. Microstructure evolution of a 3003 sheet cladded with 4004 brazing alloy is investigated during slow heating $(1 \mathrm{~K} / \mathrm{min})$ under secondary vacuum up to isothermal brazing temperature $\left(590^{\circ} \mathrm{C}\right)$. Optical and scanning microscopies, EDS chemical analysis and EBSD orientation mapping are used. Experimental results are discussed in the light of thermodynamic calculations using Thermo-Calc. Comparisons show good agreement as long as $\mathrm{Mg}$ vaporization does not take place.

\section{Introduction}

Most of aluminum heat exchangers are brazed in controlled atmosphere brazing (CAB) furnaces, using fluxes to remove the oxide layer on the brazing sheet surface. This study rather focuses on plates and fins heat exchangers brazed under secondary vacuum. They consist of alternative 4004 (clad) / 3003 (core) brazing sheets and 3003 fins. The clad layer melts and flows when the brazing temperature is reached (around $590^{\circ} \mathrm{C}$ ), permitting the junction between the parts to be assembled. Here, magnesium in the 4004 alloy plays the role of the flux [1]. A certain amount of it evaporates above $400^{\circ} \mathrm{C}$ which disrupts the oxide layer and acts as a getter to prevent from re-oxidation during brazing.

The heating rate of industrial processes is very slow, around $1 \mathrm{~K} / \mathrm{min}$ and significant long range diffusion takes place, which strongly modifies the microstructure of both alloys before the brazing itself proceeds. This results in deviation from the processing route usually admitted by metallurgists working on aluminum brazing.

The aim of this work is to precisely characterize what happens in 3003/4004 sheets during their slow heating up to brazing temperature.

\section{Materials and methods}

Since this work only deals with heating before brazing, tests were carried on a simple brazing sheet. The core is made of a 3003 alloy cladded on both sides with a $125 \mu \mathrm{m}$ thick 4004 alloy. The total thickness of the sheet is $1 \mathrm{~mm}$. The standard chemical composition of both alloys is listed in Table 1.

The 3003 alloy is characterized by its high level in manganese, while the 4004 is enriched in silicon and magnesium. Si lowers the melting point [2] whilst Mg permits the destruction of the oxide layer. 
Table 1. Chemical composition of the two Al-alloys constituting the cladded sheet (wt\%).

\begin{tabular}{|c|c|c|c|c|c|c|c|c|c|}
\hline \multirow{2}{*}{ Alloy } & \multirow{2}{*}{$\mathrm{Si}$} & \multirow{2}{*}{$\mathbf{F e}$} & \multirow{2}{*}{$\mathrm{Cu}$} & \multirow{2}{*}{ Mn } & \multirow{2}{*}{$\mathbf{Z n}$} & \multirow{2}{*}{ Mg } & \multicolumn{2}{|c|}{ Others } & \multirow{2}{*}{ Al } \\
\hline & & & & & & & Each & Total & \\
\hline 3003 & 0.60 & 0.70 & $0.05-0.2$ & $1.0-1.5$ & 0.10 & $\mathbf{0}$ & 0.050 & 0.15 & balance \\
\hline 4004 & $9-10.5$ & 0.80 & 0.25 & 0.10 & 0.20 & $1.0-2.0$ & 0.05 & 0.15 & balance \\
\hline
\end{tabular}

One single cladded sheet was cut into smaller parts on which the tests were made, thus avoiding any ambiguity in terms of chemical composition or thermo-mechanical treatments, which can differ from one supplier to another.

A heating device working in secondary vacuum $\left(10^{-4} \mathrm{mbar}\right)$ was used to perform heat treatments which consisted of a $1 \mathrm{~K} / \mathrm{min}$ heating to different temperatures followed by a rapid cooling (on the order of $20 \mathrm{~K} / \mathrm{min}$ ) to room temperature. The heating rate of $1 \mathrm{~K} / \mathrm{min}$ is closed to the industrial conditions.

Samples were then mounted in a conductive resin and polished. SEM observation and EDS analysis required a mechanical polishing, ending by a $1 / 4 \mu \mathrm{m}$ diamond suspension, while the final polishing of samples for EBSD analysis was performed with an OPS silica suspension. Optical microscope observations were carried on an Olympus BX61. SEM observation and EDS analysis were made on a Zeiss Supra 40 with a Bruker acquisition system. The interaction volume in chemical analysis is around $2.5 \mu^{3}$ for aluminum. EBSD maps were obtained with a Zeiss Supra 40 with a Bruker acquisition system (for the deformed microstructures) or with a Jeol 6490 and Oxford acquisition system.

In addition, thermodynamic calculations were performed using Thermo-Calc software and TCAL-2 database. Amounts and compositions of equilibrium phases were calculated as a function of temperature for both alloys. DICTRA software was also used to predict the diffusion profiles induced by slow heating.

\section{Results and discussion}

Initial State. Fig.1.a shows the clad alloy 4004 in its initial state. Three types of particles could be identified by EDS analysis and were found to be pure $\mathrm{Si}, \mathrm{Mg}_{2} \mathrm{Si}$ and $\pi\left(\mathrm{Al}_{18} \mathrm{Fe}_{2} \mathrm{Mg}_{7} \mathrm{Si}_{10}\right)$ phases.

In the core alloy 3003 (Fig.1.b), two types of particles can be distinguished by their size. The coarser ones, hereafter called precipitates, were analyzed by EDS to be either $\mathrm{Al}_{6}(\mathrm{Mn}, \mathrm{Fe})$ or $\alpha$ $\mathrm{Al}(\mathrm{Mn}, \mathrm{Fe}) \mathrm{Si}\left(\mathrm{Al}_{15} \mathrm{Si}_{2} \mathrm{M}_{4}\right.$ where $\left.\mathrm{M}=\mathrm{Mn}+\mathrm{Fe}\right)$ phases. Accurate EDS or EBSD analyses were not possible on the finer particles, called dispersoids, but it has been showed [3] that they should be $\alpha$ $\mathrm{Al}(\mathrm{Mn}, \mathrm{Fe}) \mathrm{Si}$ phase. Image analysis on the as-received 3003 alloy gave estimate of the volume fractions of dispersoids and precipitates to $1.6 \pm 0.2 \%$ and $3.6 \pm 0.4 \%$, respectively.

a)

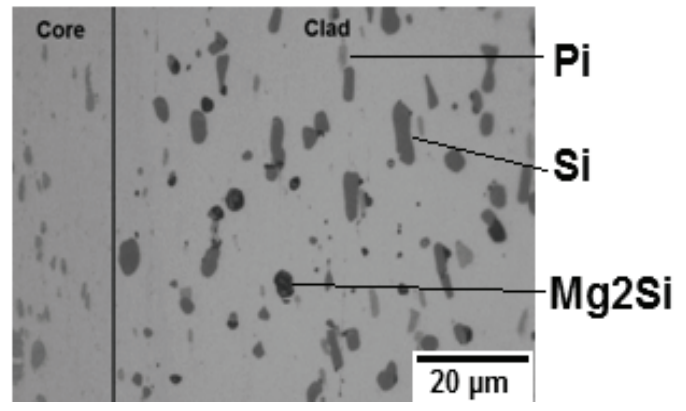

b)

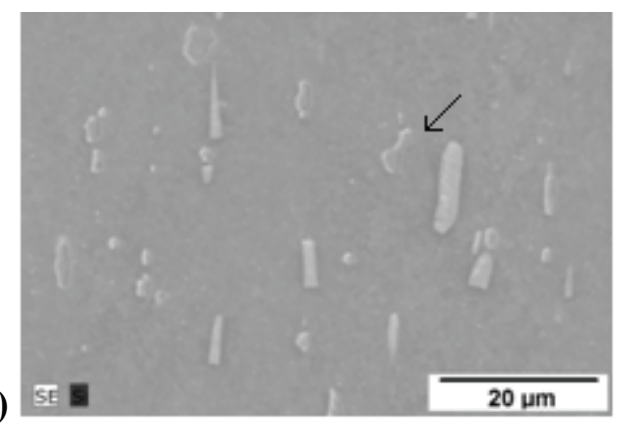

Fig.1. a) Optical micrograph of a cladded sheet at its initial state and b) SEM observation of the core alloy at its initial state coupled with EDS analysis ; Si rich particles $(\alpha-\mathrm{Al}(\mathrm{Mn}, \mathrm{Fe}) \mathrm{Si})$ appear in dark grey (see arrow) whilst the $\mathrm{Al}_{6}(\mathrm{Mn}, \mathrm{Fe})$ ones appear in light grey. Rolling direction is vertical.

Fig.2 shows two EBSD maps typical of the laminated material: grains are elongated with numerous internal misorientations. The mean equivalent diameters of 3003 and 4004 grains are around $100 \mu \mathrm{m}$ and $20 \mu \mathrm{m}$, respectively. The deformation cells inside the grains have an estimated diameter of about $1 \mu \mathrm{m}$. 
a)

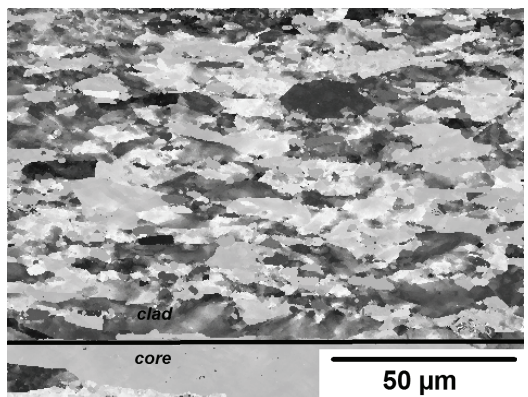

b)

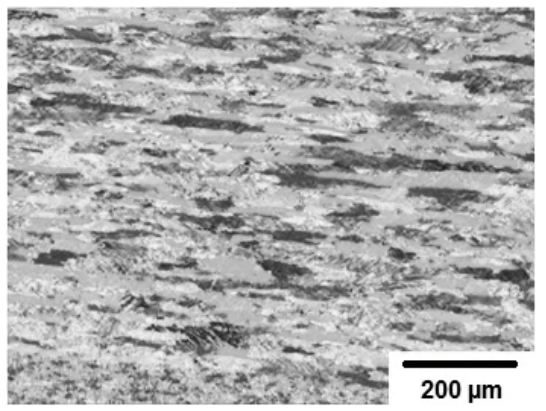

Fig.2. EBSD maps showing the grains morphology a) of the clad alloy and b) of the core alloy in their as-received state; rolling direction is horizontal.

Evolution during heating - Thermo-Calc predictions. Equilibrium compositions and proportions of the particles present in both alloys as a function of temperature were calculated by Thermo-Calc. With regard to the very low heating rate used in the present study, it is reasonable to assume that the alloy is close to this equilibrium state for each temperature during heating. However, one should keep in mind that calculations are made for homogeneous alloys and taking neither the vaporization of $\mathrm{Mg}$ nor the diffusion of Si into account.

Fig.3 reports the calculated evolution of the weight fractions of phases as a function of temperature for the clad (a) and the core (b) alloys. In the clad alloy (4004), Fig.3.a shows that no major change is expected before $555^{\circ} \mathrm{C}$, which is the temperature of formation of the first liquid and relates to a final eutectic reaction involving mainly $\mathrm{Si}$ and $\pi$ phases. That is why most of the following experimental results will concern temperatures higher than $555^{\circ} \mathrm{C}$. Above this temperature, the weight fraction of $\mathrm{Si}$ and $\pi$ particles is expected to decrease rapidly as the fraction of liquid increases while $\mathrm{Al}_{9} \mathrm{Fe}_{2} \mathrm{Si}_{2}$ particles should appear at $560^{\circ} \mathrm{C}$.

In the core alloy, as shown in Fig.3.b, no drastic change in the total amount of precipitates is expected up to brazing temperature. Indeed, the $\alpha-\mathrm{Al}(\mathrm{Mn}, \mathrm{Fe}) \mathrm{Si}$ phase is predicted to slightly grow at the expense of $\mathrm{Al}_{6}(\mathrm{Mn}, \mathrm{Fe})$.

a)

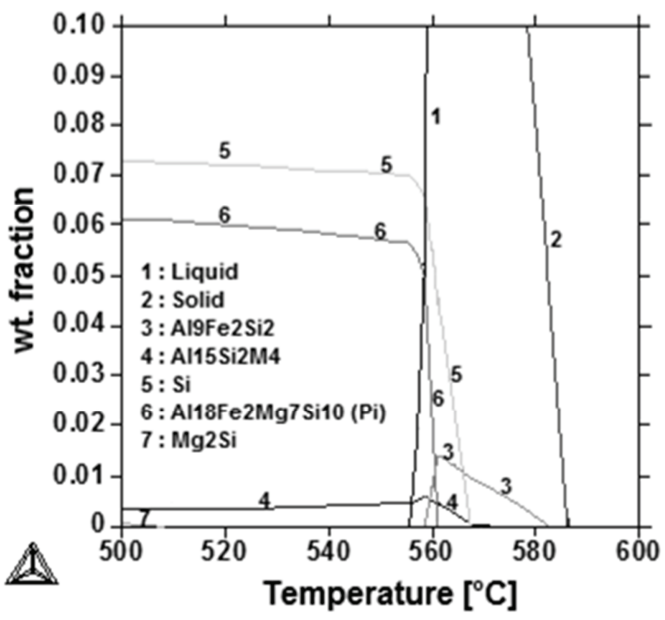

b)

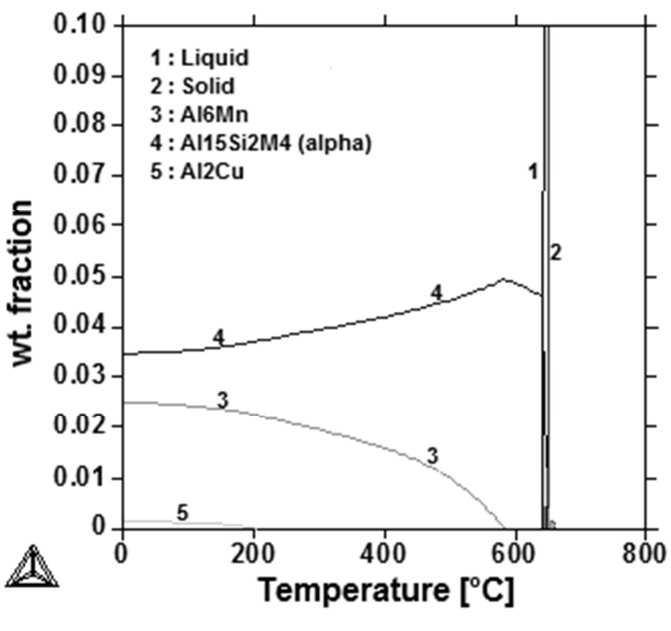

Fig.3. Thermo-Calc predictions for the evolution of the particles weight fractions a): in 4004 alloy and b) in 3003 alloy

Evolution during heating - Experimental observations. Fig.4 presents optical micrographs of cladded sheets heated to different temperatures chosen around the ternary eutectic $\mathrm{Al}-\mathrm{Si}-\mathrm{Mg}$ at $555^{\circ} \mathrm{C}$ and the binary eutectic $\mathrm{Al}-\mathrm{Si}$ at $577^{\circ} \mathrm{C}$. On all the pictures, the clad alloy is on the right side and the core alloy on the left side. These two materials can also be easily distinguished by the quantity and shape of the particles they contain. 

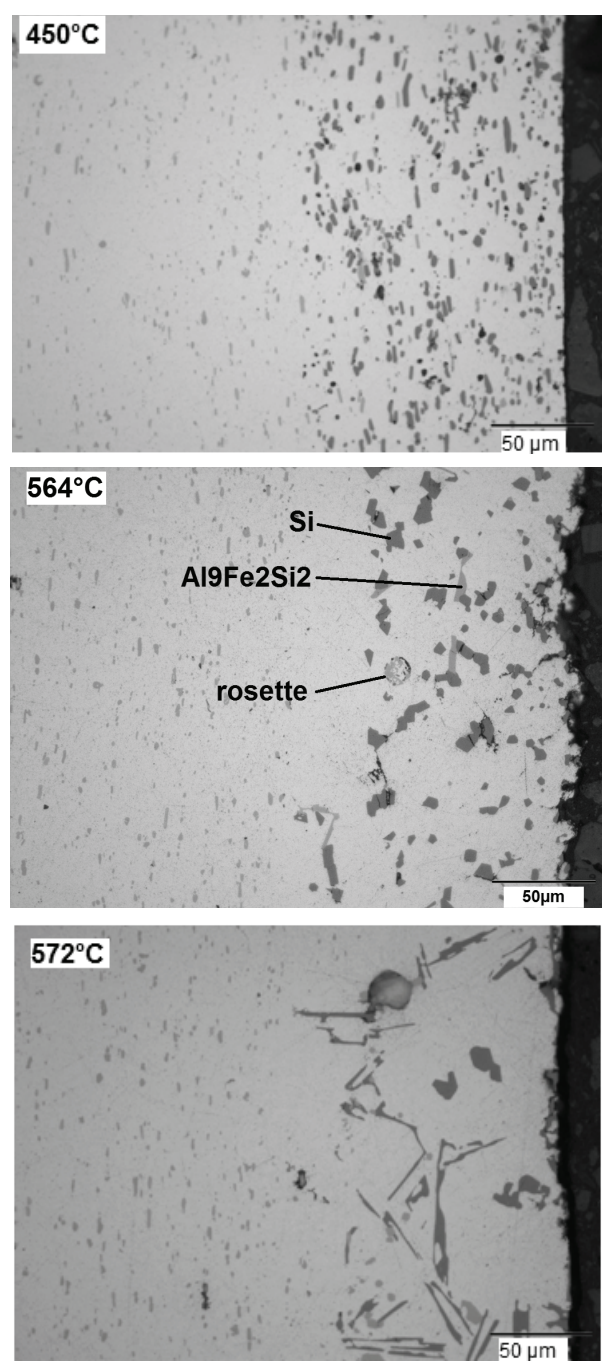
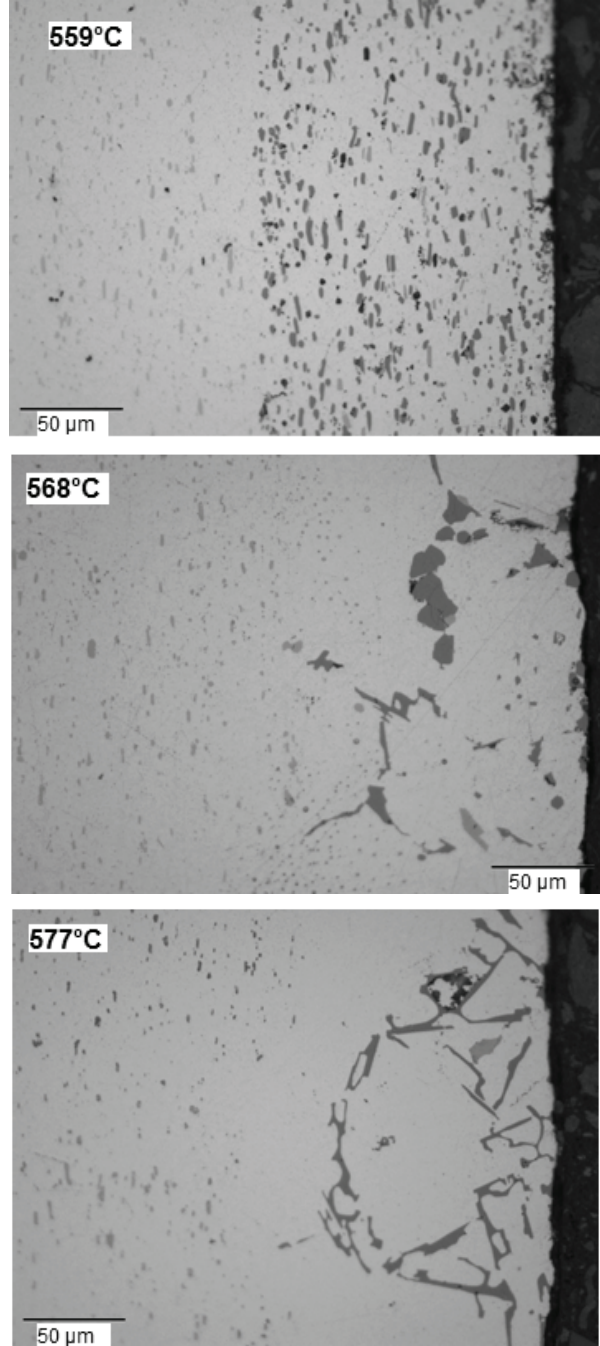

Fig.4. Optical micrographs of a cladded sheet heated to different temperatures. The clad alloy is on the right side and the core alloy on the left side of each micrograph.

Concerning 3003 core alloy, Fig.4 exemplifies no drastic evolution of the morphology of the precipitated phases during heating. EDS analysis also showed no significant change in their composition; they are still $\mathrm{Al}_{6}(\mathrm{Mn}, \mathrm{Fe})$ and $\alpha-\mathrm{Al}(\mathrm{Mn}, \mathrm{Fe}) \mathrm{Si}$ phases. Volume fractions of dispersoids and precipitates were measured far from the 3003/4004 interface as given in Table 2. It is confirmed that the total amount of precipitates is constant with a trend of coarsening, confirmed by the disappearance of dispersoids. EBSD analysis pointed out that grain recrystallization or recovery takes place very early during heating. As shown in Fig.5, it is still achieved at $428^{\circ} \mathrm{C}$, the further evolution being classical grain growth. This recrystallization has a great influence on further brazing during which the liquid clad is in contact with the solid. As mentioned by Schmatz [4], the liquid can penetrate deeper along the grain boundaries. It thus creates an enriched zone in silicon in the core alloy, which could have a strong impact on the corrosion resistance.

In Fig.5, one also can see that the grains are elongated. This tends to suggest that the major phenomenon taking place for their evolution should be rather recovery than recrystallization. This could be due to the high density of particles existing in the core alloy that prevents recrystallization, as explained by Humphreys [5].

Table 2. Volume fractions of dispersoids and precipitates in the core alloy

\begin{tabular}{|c|c|c|c|c|}
\hline & Room T. & $425^{\circ} \mathrm{C}$ & $550^{\circ} \mathrm{C}$ & $564^{\circ} \mathrm{C}$ \\
\hline Volume fraction of precipitates & $3.6 \pm 0.9$ & $3.5 \pm 0.7$ & $3.3 \pm 0.6$ & $3.6 \pm 0.7$ \\
\hline Volume fraction of dispersoids & $1.6 \pm 0.2$ & $2.1 \pm 0.3$ & $1.1 \pm 0.1$ & $0.9 \pm 0.2$ \\
\hline
\end{tabular}



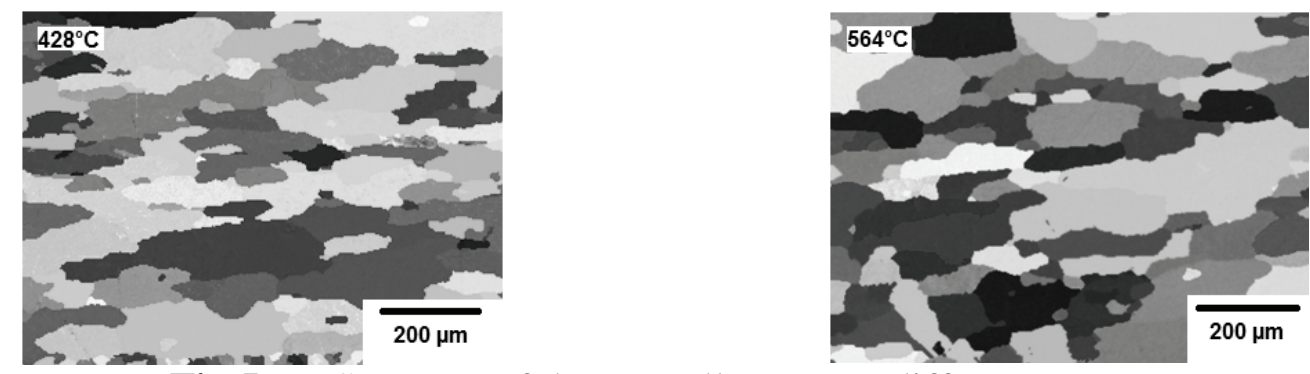

Fig.5. EBSD maps of the core alloy at two different temperatures

Concerning 4004 clad, Table 3 reports EDS analyses made on the particles detected at different temperatures. As can be seen in Fig.4 and Table 3, no major change is visible until $559^{\circ} \mathrm{C}$ for the precipitates. This is in accordance with the Thermo-Calc predictions (Fig.3.a), except for the $\mathrm{Mg}_{2} \mathrm{Si}$ phase which was present at room temperature and is still observed at $559^{\circ} \mathrm{C}$. This may be due to the lack of homogeneity in the alloy and shows that the material was not at equilibrium in its initial state. At a higher temperature, between $559^{\circ} \mathrm{C}$ and $564^{\circ} \mathrm{C}$, liquid is formed in the 4004 alloy, resulting in a drastic change in the microstructure with the melting of the eutectic containing Si and $\pi$ phases and likely the $\mathrm{Mg}_{2} \mathrm{Si}$ phase. In the micrograph for $564^{\circ} \mathrm{C}$ in Fig.4, it is seen that the $\mathrm{Si}$ particles coalesced and new coarse $\mathrm{Al}_{9} \mathrm{Fe}_{2} \mathrm{Si}$ particles are formed, which is typical of resolidification. Rosettes can also be observed [6]. The replacement of $\mathrm{Si}$ and $\pi$ particles by $\mathrm{Al}_{9} \mathrm{Fe}_{2} \mathrm{Si}_{2}$ ones was predicted to start at $560^{\circ} \mathrm{C}$ by Thermo-Calc (see Fig.3.a), in agreement with what is observed. It has been reported that the liquid resulting from eutectic melting at $555^{\circ} \mathrm{C}$ does exude on the clad surface [7]. We can assume that the Mg then evaporates, and lets a Si enriched surface. Indeed, on the samples heated to $564^{\circ} \mathrm{C}$, numerous and coarse Si particles are observed on the extreme surface of the 4004 alloy.

In addition to Mg evaporation, chemical exchanges occur through the 4004/3003 interface during the whole slow heating process. Firstly, solid state diffusion takes place. In order to reach equilibrium, Si-particles in the clad alloy dissolve and Si diffuses in the core alloy. This has been associated with the creation of a depleted zone free of precipitates between clad and core [1]. This area is visible on Fig. 4 at $564^{\circ} \mathrm{C}$. Due to the dissolution of core particles, the clad is enriched in $\mathrm{Mn}$. The resulting chemistry variation could explain the presence of $\mathrm{Mn}$ in the particles present at $568^{\circ} \mathrm{C}$, as seen in Table 3. Indeed, some $\mathrm{Mn}$ atoms substituted $\mathrm{Fe}$ atoms in the $\mathrm{Al}_{9} \mathrm{Fe}_{2} \mathrm{Si}_{2}$ precipitates, while precipitates with a composition close to $\alpha-\mathrm{Al}(\mathrm{Mn}, \mathrm{Fe}) \mathrm{Si}$ appear as previously observed [8].

Table 3. Precipitates present at high temperatures in the 4004 alloy

\begin{tabular}{|c|c|c|c|c|}
\hline Sample & Precipitates & Element & $\begin{array}{c}\text { Composition found } \\
\text { by EDS nalalsis } \\
\text { [at. } \% \text { l] }\end{array}$ & $\begin{array}{l}\text { Stoechiomertic } \\
\text { composition [at. } \% \text { ] }\end{array}$ \\
\hline \multirow{3}{*}{${ }^{559^{\circ} \mathrm{C}}$} & 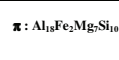 & $\begin{array}{l}\text { Al } \\
\text { Fe } \\
\text { Mg } \\
\text { si }\end{array}$ & $\begin{array}{l}5.5 \pm 3 \\
4.5 \pm 0.2 \\
16+1.0 \\
24 \pm 16\end{array}$ & $\begin{array}{l}499 \\
5,4 \\
19 \\
27\end{array}$ \\
\hline & pure Si & $\begin{array}{l}\mathrm{Si} \\
\mathrm{Ai}\end{array}$ & $\begin{array}{l}78 \pm 4,0 \\
21 \pm 4,7\end{array}$ & $\begin{array}{l}100 \\
0\end{array}$ \\
\hline & $\mathrm{Mg}_{2 \mathrm{Si}}$ & $\begin{array}{l}\frac{M}{M g} \\
\text { Si } \\
\text { il }\end{array}$ & $\begin{array}{l}221 \pm 13 \\
22 \pm 3,8 \\
26 \pm 14\end{array}$ & $\begin{array}{l}67 \\
33 \\
0\end{array}$ \\
\hline \multirow{2}{*}{${ }_{564^{\circ} \mathrm{C}}$} & $\mathrm{Al}_{3} \mathrm{Fe}_{2} \mathrm{Si}_{2}$ & $\begin{array}{l}\text { Al } \\
\text { Fe } \\
\text { Si }\end{array}$ & 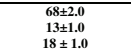 & $\begin{array}{l}699 \\
15 \\
15\end{array}$ \\
\hline & pure Si & $\begin{array}{l}{ }_{A} \mathrm{si} \\
\mathrm{Al}\end{array}$ & $\begin{array}{l}98 \pm 0.7 \\
2,3 \pm 0.7\end{array}$ & 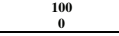 \\
\hline
\end{tabular}

\begin{tabular}{|c|c|c|c|c|}
\hline Sample & Precipitates & Element & 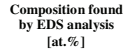 & $\begin{array}{l}\text { Stoechiomertic } \\
\text { composition [at. } \% \text { ] }\end{array}$ \\
\hline \multirow{3}{*}{$568^{\circ} \mathrm{C}$} & $\mathrm{All}_{\mathrm{l} F \mathrm{~F}} \mathrm{~S}_{\mathrm{i}}$ & 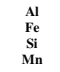 & 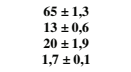 & $\begin{array}{l}69 \\
15 \\
15 \\
0\end{array}$ \\
\hline & pure Si & $\begin{array}{l}\mathrm{S}_{\mathrm{AI}} \\
\mathrm{A}\end{array}$ & $\begin{array}{l}\frac{9}{99 \pm \pm 0,1} \\
1,4 \pm 0,1\end{array}$ & 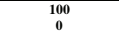 \\
\hline & $\boldsymbol{\alpha} \cdot \mathrm{Al}(\mathbf{M n}, \mathrm{Fe}) \mathrm{Si}$ & $\begin{array}{l}\mathrm{Al} \\
\mathrm{Fe}-\mathrm{Mn} \\
\mathrm{Si}\end{array}$ & $\begin{array}{c}7 \pm 0,1 \\
11 \pm 0,66-5,6 \pm 0,45 \\
11 \pm 0,22\end{array}$ & $\begin{array}{c}71 \\
\mathrm{Mn}+\mathrm{Fe} \\
9,5\end{array}$ \\
\hline \multirow[t]{2}{*}{$573^{\circ} \mathrm{C}$} & $\boldsymbol{\alpha}-\mathbf{A}(\mathrm{Mn}, \mathrm{Fe}) \mathrm{Si}$ & $\begin{array}{l}\mathrm{Al} \\
\mathrm{Fe} \cdot \mathrm{e} \\
{ }_{\mathrm{Si}}\end{array}$ & $\begin{array}{c}72 \pm 0,10 \\
10,1 \pm 0,02.6,9 \pm \\
0,48 \\
11 \pm 0,13\end{array}$ & $\underset{\substack{71 \\
\mathrm{Mn}+\mathrm{Fe}_{9,5}=19}}{2}$ \\
\hline & pure Si & $\begin{array}{l}S_{A I} \\
\text { Si }\end{array}$ & $\begin{array}{l}98 \pm 0,28 \\
2,1 \pm 0.28\end{array}$ & $\begin{array}{l}100 \\
0\end{array}$ \\
\hline
\end{tabular}

EDS analysis put in evidence the diffusion of Si in the core alloy which could be characterized by line countings. Fig. 6 shows that Si diffused over $100 \mu \mathrm{m}$ in the core alloy. This diffusion depth is in accordance with DICTRA predictions provided that the presence of precipitates is included in the calculations. 


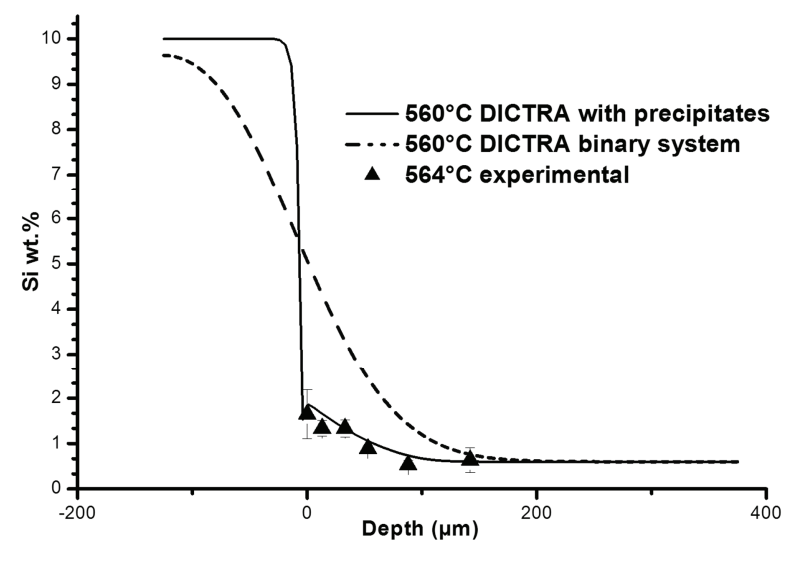

\section{Conclusions}

The evolution of the brazing sheet material during heating before reaching the brazing temperature has been studied and phenomena that have direct consequences on the brazing process have been observed. Below $564^{\circ} \mathrm{C}$, the evolution of the microstructure is well described by Thermo-Calc, while at higher temperatures diffusion of $\mathrm{Si}$ and vaporization of $\mathrm{Mg}$ take place, strongly modifying the material structure. Both calculations and experiments show that melting of the clad begins before the brazing temperature is reached. Due to this early melting, a zone enriched in Si appears at the surface of the clad alloy, and a zone free of precipitates is formed at the interface between clad and core alloys.

The diffusion of Si within the core material during the heating process takes place over an important depth $(100 \mu \mathrm{m})$ that is correctly predicted by DICTRA if the presence of precipitates in the core alloy is taken into account.

Finally, recovery and/or recrystallization is observed in the core alloy, which is expected to have a beneficial influence on brazing because it creates coarse grains.

\section{References}

[1] J.R. Terrill, C. N. Cochran, J.J. Strokes, W.E. Haupin, Understanding the Mechanisms of Aluminum Brazing can improve results in production operations, Weld. J. (1971) 833-839.

[2] J.C. Ambrose, M. G. Nicholas, Alloys for Vacuum Brazing Aluminum, One-Day Seminar "The Metallurgy of Soldered and Brazed Joints" (1986) 34-38.

[3] G.J. Marshall, R. K. Bolingbroke, A. Gray, Microstructural Control in an Aluminum Core Alloy for Brazing Sheet Applications, Metall. Trans. A 24A (1993) 1935-1942.

[4] D.J. Schmatz, Grain boundary Penetration During Brazing of Aluminum, Wel. Res. S. (1983) 267-271-s

[5] F.J. Humphreys and M. Hatherly, Recrystallization and Related Annealing Phenomena, Pergamon, 2000.

[6] S. Ahrweiler, L. Ratke, J. Lacaze, Microsegregation and microstructural feature of directionally solidified AlSi and AlSiMg alloys, Adv. Eng. Mater. 5 (2003) 17-23

[7] W.A. Anderson, Metallurgical Studies of the Vacuum Brazing of Aluminum, Weld. Res. S. (1977) 314-318-s.

[8] J. Lacaze, S. Tierce, M.-C. Lafont, Y. Thebault, N. Pébère, G. Mankowski, C. Blanc, H. Robidou, D. Vaumousse, D. Daloz, Study of the microstructure resulting from brazed aluminium materials used in heat exchangers, Mater. Sci. and Eng.A, 413-414 (2005) 317-321. 